Influența limbii materne în predarea

pronunției în limba engleză

The Influence of the Mother Tongue in

Teaching English Pronunciation

Larisa Usatîi, lector universitar, doctor în ştiinţe ale educaţiei, Catedra de Filologie Engleză, Facultatea de Limbi şi Literaturi Străine, UPS „Ion Creangă”, Chişinău ORCID: 0000-0001-6083-0311

\section{CZU: 811.111:37.016}

DOI: 10.46727/jshs.2021.v49.i3.p66-74

\section{Rezumat}

Articolul prezent tratează o problemă referitoare la influenţa limbii materne în predarea pronunţiei în limba engleză. Importanţa şi necesitatea utilizării limbii materne în învăţarea limbii engleze sunt relevante. Cunoştinţele, priceperile şi deprinderile formate în limba maternă influenţează asupra celor din limba străină; în consecință, ele relaționează, supunându-se unor legităţi concrete. Această interdependenţă poate atât să contribuie la învăţarea limbii engleze, cât şi să constituie un impediment în acest proces. Formarea deprinderilor de pronunţare corectă depinde de adaptarea sistemului fonologic al limbii materne la cel al limbii-ţintă.

Cuvinte-cheie: interferenţă, transpoziţie, limba maternă, limba străină, interdependenţă, deprinderi, cunoştinţe, pronunţare.

\section{Abstract}

The present article treats a problem regarding the influence of the mother tongue in teaching English pronunciation. The importance and necessity of using the mother tongue in learning English are relevant. The obtained knowledge, skills and abilities in the mother tongue influence those from the foreign language, as a result thezy are in an interdependence, that observe concrete laws. This interdependence can both contribute to learning English, and hinder it. The formation of correct pronunciation skills depends on the the adjustment of the mother tongue phonological system tot that of the target language.

Keywords: interference, transposition, mother tongue, foreign language, interdependence, skills, knowledge, pronunciation.

În predarea-învăţarea limbii engleze, există mai multe aspecte şi probleme de rezolvat, una dintre acestea fiind influenţa exercitată de limba maternă (română) asupra educabilului. Limba maternă este o limbă de socializare, dobândită în afara situaţiei formale de învăţământ. Limba maternă este bine însuşită şi studenţ̧ii acordă o atenţie susţinută conţinutului ei, fără să se gândească la formele de exprimare, în timp ce la învăţarea limbii engleze este necesar un efort intelectual mare, pentru a evita influenţa 
limbii materne asupra limbii engleze. Iată de ce este necesar a consolida deprinderile de percepere, inţelegere şi reproducere a materialului de limbă străină. Importanţa şi necesitatea utilizării limbii materne în învăţarea limbii engleze, consideră O. Ziuzenkova [12], n-au dispărut niciodată. $\mathrm{Cu}$ toate acestea, opiniile savanţilor referitoare la eficacitatea limbii materne, în acest context, sunt diferite. Unii cercetători văd secretul succesului la învăţarea limbii engleze în excluderea limbii materne în totalitate sau parţial din procesul de studii (adepţii metodei directe), alţii insistă asupra necesităţii analizei comparate a sistemului limbii străine şi a celui al limbii materne (adepţii metodei traducerii).

L. Scerba consideră relevantă analiza comparativ-contrastivă a limbii engleze și a limbii materne, în învățarea limbii-țintă. Practica a dovedit că ,este posibil să excludem limba maternă din procesul de studiu, însă să nu putem exclude limba maternă din conștiința educabilului” $[15$, p. 287].

Cunoştinţele, aptitudinile şi deprinderile obţinute de către studenţi la limba maternă influenţează cert asupra celor din limba engleză, iar în consecință, , limba maternă şi limba engleză sunt într-o interdependenţă complexă" [12, p. 287]. Această interdependenţă se supune unor legităţi concrete, ea - interdependenţa -
Revista de științe socioumane Nr.3 (49) 2021

https://doi.org/10.46727/jshs.2021.v49.i3

poate atât să contribuie la învăţarea limbii engleze, cât şi să împiedice.

Avantajul folosirii limbii materne la învăţarea limbii engleze constă în determinarea posibilităţilor de transfer al cunoştinţelor, priceperilor şi deprinderilor din limba maternă în limba studiată şi în elucidarea momentelor care creează condiţii favorabile pentru interferenţă. Acest lucru este posibil în baza analizei comparative a limbii engleze şi a celei materne.

Transferul (transpoziţia) unei deprinderi din limba maternă în limba-ţintă este conştient sau inconştient.

În situația când cunoștințele și deprinderile din limba maternă sunt transferate în limba de studiu, afirmă R. Lado [2], apare facilitarea de învăţare. Când deprinderea transferată nu este permisă în limba-ţintă, apare interferenţa şi studentul îşi asumă o dificultate de învăţare suplimentară. Dacă există aptitudinea de a folosi unităţile şi modelele de exprimare într-o limbă nouă limba engleză -, care sunt asemănătoare cu cele din limba maternă a studentului, atunci în funcţie de gradul de asemănare funcţională va apărea o facilitare. Dacă în procesul de învăţare a limbii engleze modul de exprimare, conţinutul şi asocierile în limba engleză sunt identice cu cele din limba maternă, va exista un maximum de facilitare. Interferenţa este condiţionată şi de faptul că domeniul de experienţă de care este nevoie la învăţarea limbii engleze este atât de asemănător cu cel 
din limba maternă, încât vor fi folosite deprinderile de limbă maternă şi, astfel, se va încetini formarea noilor deprinderi şi aptitudini pentru modelele limbii engleze [13].

Transferul apare chiar şi atunci când studentul încearcă în mod deliberat să-l evite. Puterea obişnuinţei din limba maternă îi influenţează atât auzul, cât şi vorbirea. El nu aude completamente sistemul fonetic al limbii engleze, ci filtrează ceea ce percepe auditiv cu ajutorul sistemului fonetic al limbii materne.

În opinia academicianului L. Scerba, principiul corelării limba maternă - limba engleză este unul fundamental la formarea competenţei fonologice şi este numit principiul pornirii. Or, însuşirea limbii engleze începe de la limba maternă şi anume aceasta din urmă contribuie la prevenirea greşelilor în pronunţarea şi utilizarea unităţilor segmentale şi suprasegmentale din limba engleză. Savantul menţionează că „studenţii trebuie să înveţe tot ce este nou şi greu în limba engleză, comparând fenomenele cu corespondentele lor din limba maternă; dificultăţile mari de pronunţare nu apar în procesul însuşirii sunetelor care nu au corespondente în limba maternă, ci tocmai în cazul sunetelor limbii engleze care au echivalente în limba maternă” [14, p. 83].

Cercetătorul V. Artiomov menţionează necesitatea de a îmbina corect regulile şi activităţile de comunicare din
Revista de științe socioumane Nr.3 (49) 2021

https://doi.org/10.46727/jshs.2021.v49.i3

limba străină cu cele din limba maternă [5]. Fenomenele caracteristice limbii engleze nu trebuie însuşite pe de rost, inconștient, ci conștient, comparându-le cu fenomenele din limba maternă.

L. Zinder, în baza studiilor lui L. Scerba, consideră că limba maternă a educabilului contribuie la învăţarea limbii străine, oricât de mult am dori s-o excludem: ,iată de ce, susţine el, trebuie s- $O$ transformăm din duşman în prieten şi ajutor" [11, p. 94].

În limba maternă, totul este simplu şi clar şi nimic nu trezeşte nedumeriri, limba străină învăţată în plan comparativ cu cea maternă creează posibilităţi de a determina diverse căi de exprimare în limba maternă, de a descoperi diferite nuanţe, neobservate anterior.

Învăţarea limbii engleze poate fi „definită prin prisma testelor de limbă”, susţine R. Lado [2, p. 186]. Unităţile din limba engleză care sunt asemănătoare cu cele din limba maternă sunt uşor recunoscute de către studenţi. Momentul critic, la învăţarea limbii engleze, se referă la unităţile care nu pot fi transferate din limba maternă, deoarece ele nu există în limba maternă sau sunt foarte diferite. Dacă aceste unităţi dificile au fost însuşite, înseamnă că studentul a învăţat limba engleză, lucru constatat prin aplicarea testelor de verificare a însuşirii unităţilor segmentale şi suprasegmentale ale limbii engleze, care se deosebesc de cele din limba 
română. De exemplu: monoftongii posteriori de lungă durată, care lipsesc în limba română [u:, ৩:, a:]; accentul, intonaţia, tonurile, ritmul etc. din limba engleză se deosebesc de cele din limba maternă.

Limba străină este folosită în plan social; engleza, fiind privilegiată în viaţa publică, este o limbă de mediere a cunoaşterii. Limba engleză, predată şi învăţată ca atare, este o limbă de comunicare în viaţa cotidiană, folosită în interacţiunea dintre persoane sau dintre persoane şi instituţii.

În condiţiile societăţii contemporane şi ale modernizării sistemului de învăţământ, au prioritate nu informaţiile, ci competenţele care vor fi formate. Atunci când se predă o limbă străină, nematernă, este necesar ca profesorul să vegheze permanent la buna însuşire a pronunţiei, deoarece numai astfel se pot atinge progresul şi acurateţea în pronunţare. Însuşirea pronunţiei nu se realizează separat de învăţarea limbii în întregime.

Limba este un instrument de comunicare şi de interacţiune socială. Învăţarea limbii într-un mediu bilingv le oferă posibilitate studenţilor să-şi diversifice tipurile de discurs, să-şi îmbogăţească experienţa şi să-şi consolideze competenţa lingvistică. Acest lucru îi obligă să utilizeze toate resursele, competenţele şi aptitudinile, pentru a fi personalităţi interculturale. Studenţii trebuie obişnuiţi să-şi dezvolte
Revista de științe socioumane Nr.3 (49) 2021

https://doi.org/10.46727/jshs.2021.v49.i3

abilităţile de scriere şi citire în ambele limbi: maternă şi străină, accentul fiind pus pe dezvoltarea competenţelor comunicative.

R. Lado [2, p. 87] susţine că pentru pronunţie corectă este nevoie de ,trei niveluri de acurateţe, şi anume: acurateţe în scop comunicaţional; acurateţe în predare, oferită de profesorul de limbă, şi acurateţe în folosirea celei de a doua limbi ca limbă naţională, performanţa lingvistică”. În predarea limbii engleze, este bine să se ţină cont de specificul limbii. $O$ parte din problemele care apar la învăţarea limbii engleze se rezolvă uşor în perioada orală, care are rolul de a asigura formarea deprinderilor de pronunţare corectă, mai ales la adaptarea sistemului fonologic al limbiiţintă. În astfel de cazuri, se cere a fi respectat următorul traseu: conştientizarea fenomenului - inţelegerea lui - exersarea conştientă - exersarea în comunicare.

Înlocuirea unui sistem de sunete cu un alt sistem reduce inteligibilitatea informaţiei transmise. Când o persoană foloseşte sistemul fonetic al limbii materne în limba-ţintă, auditoriul va avea reacţii la accentul său; aceste reacţii depind de persoana care ascultă, de felul cum foloseşte ea limba în comunicare.

O percepţie auditivă imperfectă a sistemului fonetic duce la o memorare mai puţin temeinică a mesajelor. Îmbunătăţirea pronunţiei, în cadrul percepţiei auditive, va 
duce la o memorare mai bună şi la o comunicare corectă.

Noţiunea de ,interferenţă” a limbii materne, la însuşirea limbii străine, a fost considerată ca o primă sursă de comitere a greşelilor. În locul ei, a apărut conceptul de „transfer lingvistic” al caracteristicilor limbii materne în limba studiată, care poate fi atât pozitiv (în cazul caracteristicilor fonologice asemănătoare), cât şi negativ (în cazul când aceste caracteristici lipsesc în limba maternă).

Dacă limba maternă stimulează învăţarea limbii engleze, dacă activitatea de comunicare se realizează mai productiv în baza limbii materne, o astfel de influenţă a limbii materne se numeşte transpoziţie, sau transfer. Dacă studentul transferă programul de comunicare care a fost însuşit în limba maternă în limba engleză astfel încât norma limbii engleze nu este respectată, o astfel de influenţă a limbii materne încetineşte învăţarea limbii engleze. Acest fenomen se numeşte interferenţă. În acest caz, nu se atestă asemănări între limba maternă şi cea străină. Esenţa interferenţei presupune că cel care învaţă limba străină nu identifică, în realitate, similitudinile dintre limba maternă şi limba străină [12, p. 287].

Cei care învaţă limbi străine caută în mod conştient asemănări, puncte de referinţă între limbi, cu scopul de a facilita procesul de învăţare, susţine O. Nagy-Szilvester [8, p. 739]. La începutul procesului de achiziţie, cunoştinţele din domeniul limbii engleze sunt minime, de aceea studenţii recurg la limba maternă, care este un punct de referinţă şi constituie mecanismul de bază al transferului lingvistic. Transferul lingvistic prezintă influenţa cunoaşterii anterioare de limbă cu privire la achiziţionarea unei alte limbi.

Transferul conştient sau inconştient constă în preluarea elementelor, structurilor şi caracteristicilor limbii-sursă în limba-ţintă. Majoritatea studiilor referitoare la transferul lingvistic s-au concentrat, în opinia savanţilor De. Angelis şi L. Selinker [5], în special asupra influenţei limbii materne asupra limbii străine.

$\mathrm{Nu}$ trebuie neglijată nici importanţa distincţiei între transferul pozitiv şi cel negativ [7]. Transferul pozitiv ajută studentul la achiziţionarea unei limbi noi, însă s-a constatat că acesta are loc în cazul a două limbi asemănătoare. Termenul interferenţă, de regulă, coincide cu termenul transferul negativ, defectuos al elementelor lingvistice, care este un fenomen eronat şi afectează negativ performanţa celor care învaţă limba engleză.

„Teoria transferului este strâns legată de analiza contrastivă”, susţine E. Macaro [7, p. 77], care se concentrează asupra comparaţiei sistemice a limbilor, vizând identificarea dificultăţilor pentru studenţi. În opinia acestui savant [Idem p. 78], „conştientizarea lingvistică” este o noţiune legată de transferul lingvistic, centrată pe ideea de înţelegere a modului în care 
funcţionează limba, subliniind diferenţele şi asemănările dintre limba maternă şi limba engleză.

Transferul lingvistic negativ, sau interferenţa lingvistică, este deseori abordat în studiile lui E. Macaro et al. [Idem, p. 67], împreună cu teoria ,fosilizării lingvistice”, a transformării lingvistice. Acest fenomen se referă la formele lingvistice deviate. La această etapă, limba studenţilor este la un nivel intermediar, incomplet, uşor influenţat.

Lecțiile de limbă engleză cu studenţii care au diferite niveluri de competenţe şi cunoştinţe în limba engleză oferă numeroase exemple de transfer lingvistic. Elementele de transfer lingvistic negativ sunt comune la nivelurile începător şi mediu. Studenţii cu cunoştinţe de limbă română începători care studiază limba engleză întâmpină dificultăţi privind pronunţia [8], întrucât limba maternă are un sistem fonologic destul de clar, semnalat prin alfabetul său, în timp ce limba engleză nu marchează fiecare sunet specific cu litere strict corespunzătoare. De exemplu, o eroare fonologică o constituie pronunţarea monoftongilor posteriori de lungă durată.

S. Gass, L. Selinker, de asemenea, abordează noţiunile de ,transfer lingvistic al limbii materne” şi cea de ,interferenţă” şi specificul lor [6].

Transferul negativ, sau interferenţa, are loc la toate nivelurile, însă interferenţa fonetică (fonologică) este cea mai pronunţată. L Zilberman [10] constată că în procesul de
Revista de științe socioumane Nr.3 (49) 2021 https://doi.org/10.46727/jshs.2021.v49.i3

învăţare a limbii engleze este posibilă interferenţa fonetică, drept urmare a existenţei vocalelor lungi şi scurte, care în unele limbi au importanţă fonematică, iar în altele, nu au. Acest fapt condiţionează o pronunţare incorectă şi o comprehensiune proastă. Folosirea improprie a anumitor structuri morfologice constituie cazuri de transfer lingvistic. Studentul transferă în mod conştient structuri din a doua sau a treia limbă în cea engleză, folosind structurile limbii-sursă ca modele pentru produsul de limbă engleză. Cazurile de interferenţă gramaticală includ, în general, erori privind ordinea cuvintelor, timpurile verbale, gradele de comparaţie ale adjectivelor, structura propoziţiilor şi altele.

Propoziţia engleză care necesită un subiect, fie chiar unul formal, este un alt caz de transfer negativ - interferenţă [8, p. 743]. De exemplu: în limba română - Plouă, în limba engleză - It is raining.

Utilizarea corectă a prepoziţiilor în limba engleză cauzează dificultăţi pentru studenţi, deoarece ei recurg la limba maternă ori la o altă limbă învăţată anterior, care uneori are rolul de facilitare, iar alteori studenţii sunt induşi în eroare de aceasta. De exemplu: a cânta la pian - în română, to play the piano - în engleză (în limba engleză, lipseşte prepoziţia); a fi acasă - în română, to be at home - în engleză (în acest caz, prepoziţia lipseşte în limba română). 
Interferenţele lexicale apar atunci când studenţii vor să compenseze lapsusurile din vocabular, împrumutând morfeme ori cuvinte din alte limbi, pentru a se exprima. De exemplu: He bit his language în loc de $\mathrm{He}$ bit his tongue (a muşcat limbajul său, în loc de şi-a muşcat limba). Polisemia cuvintelor, expresiile idiomatic, în limba engleză, de asemenea, generează erori lexicale.

Capacitatea scăzută de a imita corect noile sunete din limba engleză este scăzută, deoarece studenţii le aud prin prisma deprinderilor de pronunţare ale limbii lor materne, care s-au imprimat adânc în obișnuință. Deci, în opinia savantei A. Tătaru [3, p. 176], ,interferenţele din limba maternă şi interpretarea greşită a grafiei cuvintelor noi sunt dificultăţi foarte importante", de aceea, cunoaşterea contrastivă a sistemului de pronunţare al limbii engleze, faţă de cel al limbii materne, care poate fi dezvoltat pe parcursul vieții, îl poate ajuta în mod substanţial pe adult să evite substituirile spontane sau chiar voite de sunete. Asemănările nu reduc, ci adesea înmulţesc dificultăţile în ceea ce privește însuşirea corectă a pronunţării structurilor lingvistice de către străini. De aceea, cunoaşterea lor este tot atât de importantă, ca şi cunoaşterea deosebirilor [Idem p. 171].

Fluxul pronunţării în limba engleză este adesea atât de continuu, încât, frecvent, afectează distingerea cuvintelor în context. Această trăsătură, foarte importantă, a deprinderilor de pronunţare în limba engleză
Revista de științe socioumane Nr.3 (49) 2021

https://doi.org/10.46727/jshs.2021.v49.i3

este susţinută mult şi de durata scăzută a silabelor neaccentuate faţă de cele accentuate. Vocalele lungi şi scurte dau acestei impresii acustice de fluiditate o notă specifică, imprimând ritmului pronunţării armonia necesară. Accentele sintactice joacă un rol important în trăsăturile enumerate, ca şi faptul că limba engleză, deşi germanică de origine, având tendinţa accentuării cuvintelor pe prima silabă, cuprinde multe cuvinte de origine romanică, cu accentele şi pe alte silabe.

Avantajul analizei contrastive a limbii materne şi a celei engleze rezidă în faptul că aruncă lumină egală asupra fiecărui sistem în parte. Cercetările elementelor suprasegmentale - accentul, intonaţia, ritmul - relevă faptul că ele constituie o parte importantă a competenţei fonologice, relevă caracteristicile proprii ale limbii materne şi ale limbii engleze. Cercetarea contrastivă are două trepte: prezentarea paralelă comparativă a sistemelor fonologice faţă de cele grafemice ale limbilor date, urmată de analiza contrastivă propriu-zisă a sistemelor lor de pronunţare. Analiza contrastivă, în opinia cercetătoarei A. Tătaru, determină şi descrie problemele pe care vorbitorul unei limbi le vor întâmpina la învăţarea altei limbi; astfel, autoarea prezice şi explică greşelile pe care studentul le va comite din cauza interferenţei limbii materne în procesul de învăţare a limbii engleze. Rezultatele acestei analize 
îmbogăţesc atât teoria, cât şi practica limbii străine [3].

Cunoştinţele despre diferenţele şi asemănările dintre limba maternă şi limba engleză sunt necesare atât pentru elevi, cât şi pentru studenţi, dar la un nivel diferit. A. Chirdeachin [1] susţine că influenţa limbii materne este cauza principală a greşelilor în procesul însuşirii celei străine, iar în unele cazuri, intervine şi impactul altei limbi străine, învăţată anterior ori concomitent cu limba engleză.

În concluzie, se poate spune că relaţia dintre limba maternă şi limba străină, în procesul de studii, are trei aspecte: interferenţa, transferul pozitiv şi folosirea limbii materne ca sursă ajutătoare la învăţarea limbii engleze. Necesitatea aprecierii interferenţei în procesul de învăţare a limbii engleze la diferite niveluri este foarte importantă. Ea apare la diferite niveluri din cauza multilingvismului.

Acest articol a fost scris în cadrul proiectului „TOWARDS EUROPEAN UNIVERSITY LIFELONG LEARNING MODEL IN MOLDOVA-COMPASS", cofinanţat de Comisia Europeană, prin programul Erasmus + , Nr. 597889EPP-1-2018-1-MD-EPPKA2-CBHE-SP.

\section{Bibliografie}

1. CHIRDEACHIN, Al. Fonetica limbii engleze. Chișinău: ULIM, 2014.
Revista de științe socioumane Nr.3 (49) 2021

https://doi.org/10.46727/jshs.2021.v49.i3

2. LADO, R. Predarea limbilor. O abordare ştiinţifică. Bucureşti: Editura Didactică şi Pedagogică, 1976.

3. TĂTARU, A. Limba română. Specificul pronunţării în contrast cu germana şi engleza. Cluj-Napoca: Editura Dacia, 1997.

4. VERDEŞ, M.-R. Formarea competenţelor de comunicare în limbaengleză la studenţii în drept. Teză de doctor în pedagogie. Chişinău: Tipografia UPS „Ion Creangă”, 2018.

5. DE ANGELISS, G, SELINKER, L. Interlanguage Transfer and Completing Linguistic Systems in the Multilingual Mind. În: Cross-linguistic Influence in Third Language Acquisition: Psycholinguistic Perspectives, edited by Jasone Cenoz Britta Hufeisen, Ulrike Jessner. Cleventon: Multicultural Matters, 2001, pp. 42-58.

6. GASS, S., SELINKER, L. Second Language Acquisition: An Introductory Course. Taylor \& Francis, 1994.

7. MACARO, E., VANDERPLANK, R., MURPHY, V.A. A Compendium of Key Concepts in Second Language Acquisition. In: The Continuum Companion to Second Language Acquisition, edited by Ernesto Macaro. London: Continuum, 2010, pp. 26-106.

8. NAGY-SZILVESTER, O. Linguistic Transfer in Foreign Language Acquisition. Discourse as a Form of 
Multiculturalism in Literature and Communication. Section of Language and Discourse. Arhipelag XXI Press, Tîrgu Mureş, 2015, pp. 739-748.

9. PRIGORSCHI, C., Vasilache C., Didactique du français langue étrangère. Chişinău: Editura Poligrafică Tipografia Centrală, 2006.

10. ЗИЛЬБЕРМЕН, Л.И. Интерференция языков и методика преподавания иностранного языка на основе родного. В кн.: Преподавание иностранных языков и его лингвистические основы. Москва: Наука, 1972, с. 20-33.

11. ЗИНДЕР, Л.Р. МАСЛОВ, Ю.С. Л.В. Щерба - лингвист-теоретик и педагог. Санкт-Петербург: Наука, 1982.

12. ЗЮЗЕНКОВА, О.М. О роли родного языка при обучении иностранному. В кн.: Преподавание иностранных языков и его лингвистические основы. Москва: Наука, 1972, с. 285292.

13. Интерференция звуковых систем/Под. ред. Л.В. Бондарко, Л.А. Вербицкой. Ленинград, 1987.

14. ЩЕРБА, Л.В. Преподавание языков в школе: общие вопросы методики. Санкт-Петербург: Филол. ф-т СПб ГУ, Москва: Изд-кий центр Академия, 2002.
Revista de stiinte socioumane Nr.3 (49) 2021

https://doi.org/10.46727/jshs.2021.v49.i3

15. ЩЕРБА, Л.В. Языковая система и речевая деятельность. Санкт-Петербург: СПб ГУ, 2004.

\section{Lectura - factor decisiv în formarea și dezvoltarea}

personalității elevilor de vârstă școlară mică

\section{Reading - a decisive factor for the young school age pupil}

\section{Natalia Rufanda, învățătoare de clasele primare,} grad didactic I, IP Gimnaziul nr. 53, mun. Chișinău

ORCID: 0000-0002-5977-8955 CZU: 373.3:028

DOI: 10.46727/jshs.2021.v49.i3.p74-79

\section{Rezumat}

Lectura constituie unul din factorii decisivi prin care elevul de vârstă școlară mică învață să-și formeze priceperi și deprinderi, să acumuleze aptitudini, dar și să ia atitudine. Un rol primordial în această dezvoltare îl ocupă școala, familia și, bineînțeles, metodele și mijloacele prin care elevii receptează textele.

Cuvinte-cheie: lectură, texte literarartistice, personalitate (a elevilor de vârstă școlară mică), motivație, metode (tradiționale/activ-participative).

\section{Abstract}

Reading is one of the decisive factors through which the young school age student 